\title{
Russian Foreign Policy: A Window of Opportunity in Southeast Asia
}

\author{
Arunrat Jinda \\ Public Administration Program \\ Valaya Alongkorn Rajabhat University \\ under the Royal Patronage \\ Pathum Thani, Thailand. \\ arunrat@vru.ac.th
}

\begin{abstract}
The article has analyzed the foreign policy of Russia in the Southeast Asia which developed according to dynamics of the international processes, with the purpose to strengthen political stability and to expand influence of Russia on the modern world. The developments of the foreign policy doctrine attended to the regions important for Russia from the point of view of cooperation for development, and also political, economic and social efficiency is characteristic. Especially multilateral diplomacy is one of effective methods of protection of national interests of Russia. This paper focuses on the concept of foreign policy of Russia in Southeast Asia as partners for developing many frameworks and the analysis interaction of the countries of Southeast Asia is developed by structures of cooperation that occurs at the different levels. The result is discovered and suggestions are made.
\end{abstract}

\section{Keywords - Foreign policy; Russia; Southeast Asia}

\section{INTRODUCTION}

The concept of foreign policy of the Russian Federation reflects the Russian ideas of the modern world. The concept opens processes which happen around the world and its main areas in the globalization. This article serves as the base for the Russian strategy of foreign policy which corresponds to qualitatively new geopolitical situation. In the present time, the Russian foreign policy exists in qualitatively new format answering a new world order with the multi-polar reality extending at all levels of cooperation [1].

The foreign policy of the Russian Federation developed according to dynamics of the international processes, with the purpose to strengthen political stability and to expand influence of Russia on the world scene. To development of the foreign policy doctrine the attention to the regions important for Russia from the point of view of cooperation for development, and also political, economic and social efficiency is characteristic. Such multilateral diplomacy is one of effective methods of protection of national interests of the Russian Federation in foreign policy [2]. Russia professes the multi-vector foreign policy based on clear understanding of its potential and responsibility, readiness to equal on mutually beneficial cooperation with other countries.

The strategic priority Russia sees Asia and the Pacific Rim [3]. and wishes to see itself as the leading partner. Meanwhile, China, the USA, Japan also want to have influence in this region and have in it the national interests because the Pacific Rim has natural resources, such as oil, natural gas also, besides, is the transit region.

The foreign policy of Russia is oriented to Southeast Asia which is a part Asia-Pacific the region. Russia considers that Southeast Asia - "window of opportunities" and this vision leads the Russian Federation to presence in the Pacific Rim on means of the ASEAN organization. Moreover, leaders of Russia and the states of Southeast Asia several times exchanged top-level official visits, than proved full large-scale partnership, having signed the intergovernmental agreement about cooperation of Russia and an ASEAN.

Relevance of attention to the Southeast Asia (SEA) is caused Southeast Asia is important from the point of view of geopolitics in the Pacific Rim which became the new important center of regional and international contacts. The states of an ASEAN, nevertheless, play very important role in drawing attention of large geopolitical powers. Value of this region in worldwide policy is in many respects determined by the numerous crossing interests and coincidence of interests by a number of global problems. Besides, interaction of the countries of Southeast Asia is developed by structures of a cooperation that occurs at the different levels: economic, political, socio-cultural [4].

\section{The Main DiReCtion Of Policy \\ RUSSIAN FEDERATION AND SOUTHEAST ASIA} IN THE MODERN WORLD.

\section{A. Foreign policy priorities of the Russian Federation at the present stage.}

The foreign policy of Russia developed and changed after disintegration of the Soviet Union in 1991 eventually. At the beginning of 1993-2008 the Russian foreign policy was concentrated on development of the country, to stability within policy and economy. In 2013 concepts of foreign policy reflects the Russian ideas of the modern world, and also tasks and the purposes [5]. The concept covers processes which happen around the world and its main regions.

The concept of foreign policy of the Russian Federation drew attention of experienced community. First of all it is the document which allows the big power to calibrate its provision and the status in the light of global geopolitical 
changes of the modern world: "The liability of Russia to construct foreign policy in the changeable and fast changing world" [6]. Thus, the foreign policy shall be emphasized under above-mentioned circumstances. First, the preference shall be this to cause multilateral model of action. Secondly, the West, namely, the USA shall be acknowledged as the main competitor. Thirdly, Russia will be more active in the international relations

\section{B. New priorities of the Russian foreign policy in the region.}

In the present time the Pacific Rim and the Southeast Asia- these regions which represent the greatest interests and are considered the most dynamically developing geopolitical space and is considered as future center of world economy and policy [7]. For example, the visiting of the Russian leader in Vietnam in November, 2013 was directed to enhancing cooperation with Vietnam which is one of priorities of Russia in its Asian policy.

Russia aims to economic development in the region of Siberia [8]. The development of the relations with the East as one of structural development of the Russian economy. Moreover, Russia considers the mechanism the Summit of the countries of East Asia as the main platform for strategic dialogue between leaders in key problems of safety and cooperation. Efforts in this region will be supported by actions in other formats, such as the Forum "Asia-Pacific Economic Cooperation" (APEC), Dialogue of ASEAN Russia, ASEAN the Regional Forum on safety (HARPS), the Asia-European Forum (ASEM), the Conference on interaction and on enforcement of trust in Asia, the Meeting of Ministers of Defense of an ASEAN with partners in dialogue and the Asian forum of Dialogue of the Cooperation. Russia aims to deepen consistently the strategic partnership with Vietnam and to increase cooperation with other state members of an ASEAN [9].

It is necessary to tell that Russia has political and economic cooperation with the countries in the Pacific Rim and in Southeast Asia, especially with an ASEAN. On the other hand, many countries, such as the USA and the European countries also aim to develop the relations with these countries and want to act influence in this region therefore, Now Russia stimulates its role in the Pacific Rim and Southeast Asia such as Russia became the partner of Vietnam and is also the largest countries which sell weapon to armed forces and a role of economic interests with Singapore and Thailand and others countries in the future.

\section{Southeast Asia in modern Russia of foreign policy.}

After disintegration of the Soviet Union, Russia aimed to develop and improve internal and economic politics. The relations between Russia and Southeast Asia began with the 2000th, in case of presidents Vladimir Putin and Dmitry Medvedev. The country covered "Asian" or "East" foreign policy, having concentrated on strengthening of diplomatic and commercial ties with East and Southeast Asia [10].

The changing of a global economic and strategic balance in east direction, traditionally oriented to Europe,
Russia began to understand the Asian measurement and potential. The main driver of this new strategic orientation there was an economic development accompanied with effort to watch the biggest neighbor in the region for the People's Republic of China and to approve its line item of the remarkable power in the Pacific Rim.

For last decade the relations between Russia and Southeast Asia developed on multilateral and at the bilateral levels, from economic and political a cooperation, in the most sensitive areas of contacts of protection and safety [11]. Interest of the Association of Southeast Asian Nations (ASEAN) consists in creation of a regional cooperation which smoothed the intense relations between the power of the People's Republic of China and the USA in the Pacific Rim. Thus, change of the relation of Russia to Asia is stimulated more policies- a possibility of economic development in the region increasing Asia-Pacific. Despite, the official declarations about "Asian" change in the Russian foreign policy and cooperation [12].

Russia tried to develop the relations with the ASEAN and to be included in Asia-Pacific the region. After Vladimir Putin was chosen as the president in April, 2000 [13] 3 reasons of interest of Russia in this region included;

- Recognition of importance Asia-Pacific the region for development of Russia. Economic development "Siberia and the Russian Far East" demanded closer integration with Asian regional institutions.

- Balance influence of the People's Republic of China and the USA to extend the power in the Pacific Rim and Southeast Asia.

- Political and economic development of Russia needs the Pacific Rim and Southeast Asia as Russia considers that this region can be developed and expanded in this direction in the future. Besides, Russia aimed to expand sales of weapon to the countries of an ASEAN: Vietnam, Malaysia, Indonesia and Thailand. When the East Asian summit in Southeast Asia was held in Kuala Lumpur in December, 2005, Russia was ready to accept a new role in Southeast Asia [14].

Policy of Russia in Southeast Asia now enhancing cooperation with the states of Southeast Asia and the Association of Southeast Asian Nations (ASEAN) takes the important place in priorities of the Russian foreign policy on the Far East direction. Russia serves strengthening and diversification as a bilateral cooperation between Russia and Southeast Asia through the ASEAN organizations [15]. Moreover, the expansion of institutional base a cooperation between Russia and an ASEAN in forms of the summits with participation of heads of states.

Accession of Russia to work of the East Asian summit and the Asia-Europe Meeting (ASEM) will become an important factor of strengthening of the relations between Russia and an ASEAN. These dialogue platforms will serve as important additional communication channels between the parties, promoting building-up of the quantitative party of their interaction [16]. Moreover, agreements and contracts 
which Russia signed with Southeast Asia such as the Forum of an ASEAN concerning regional security of "HARPS", the Asia-Pacific Economic Cooperation of "APEC", the East Asian summit "SEA", and also numerous unofficial structures [17]. In fact, the ASEAN carries out a backbone role, connecting all elements of institutional structure of the Pacific Rim.

The relations between Russia and the countries of Southeast Asia in there is also a complex of limiting factors. Especially, in political spheres as Russia gives paramount value to the relations with ASEAN. Russian participation in the solution of political instability and disorders in the countries and Southeast Asia for example, conflicts in Cambodia. Russia has sent educational armed forces to Cambodia and modern weapon and military equipment and also territorial conflicts in the South China Sea which have arisen between Vietnam and China with neighboring countries [18]. Russia participates in armed forces, including submarines and military weapon. Russia wants to help Vietnam and a point of access to the South China Sea because it will have to counterbalance the power of the USA and the People's Republic of China, and also Japan [19].

It is possible to tell that stability and safety in Southeast Asia can be reached with participation Russia which becomes the important mechanism in the solution of these problems. Sale of the Russian modern weapon and military equipment for armed forces to many Southeast Asian countries, such as Vietnam, Indonesia, Myanmar, Malaysia and Thailand can promote the need to counterbalance influence of the People's Republic of China which is located about this area. The People's Republic of China - the leader of geopolitics of Southeast Asia also moves an economic superpower. USA- the leader of the "Armed Forces of the Countries of the World"[20]. Besides, Russia intends to expand the power in the Pacific Rim. It is possible to tell that Southeast Asia is strategically important point in development of the Russian foreign policy and success in the future.

\section{FEATURES OF SOUTHEAST ASIA AS DIRECTIONS OF THE RUSSIAN FOREIGN POLICY}

\section{A. Specifics of national interests of the Russian Federation in Southeast Asia.}

The foreign policy of Russia after the Cold War was change in the concept of "the multipolar world" [21]. The foreign policy of Russia in system of the international relations is determined by three common foreign policy goals which are multipolarity as an equilibration of global processes, regional security and economic interests. Foreign policy under presidents of Russia of Vladimir Putin - one of the most important aspects of the current foreign policy of Russia shall protect national interests of the country, especially national interests in Asia and in Southeast Asia. After the president Putin was elected the president of Russia in 2000 the reviewed concept of "homeland security" and a new concept of foreign policy were accepted by him [22]. In both from these documents economic problems were placed in the center of the long-term national development strategy. The concept of "foreign policy" declared in particular it to guarantee a homeland security of Russia and to increase its sovereignty and territorial integrity. They can concern 3 points [23].

- Promotion of the economic relations

- Promotion of military safety

- Creation of the peace and joint regional environment.

Within the first decade of the 21 st century Russia continued to show the steady intention to support the size of its regular forces in east part of the country at the level of the minimum sufficient safety. And considered quite important to emphasize that the Russian national interests in Asia and Southeast Asia were regarding national interests of the regional countries [24].

Besides, the Russian leaders told that benefit will bring them Russia into a superpower in political, economic, social spheres. The national interests of Russia is a method of Russia to play more and more important role on the world scene and in quality the concept "superpowers", and probabilities of establishment of the multipolar world.

\section{B. National priorities and national interests Russian}

Federation: National interests of Russia in Southeast Asia.

The concept of foreign policy of the Russian Federation, accepted by Dmitry Medvedev, the new president of Russia, promoting the relations with the countries and the international organizations of the Asia-Pacific Region (APR) were depicted in general as the highest priority. The important direction of this strategy which should be developed both in a concept and in practice there was Southeast Asia. At the same time, the chief Russian officials repeatedly emphasized that cooperation with the certain Southeast Asian countries and the Association of Southeast Asian Nations (ASEAN) had considerable potential and Southeast Asia and Russia will provide essential strategic benefits to both [25].

The foreign policy of the Soviet Union consisted in strong national interests in Southeast Asia. They are created not by simple geography, but a rich variety of political, economic, cultural and other factors. Obviously, in various periods of the Soviet and Russian history some of these factors of steel more visible, than others, thus, influencing the choice of national interests of Russia, but in this period Southeast Asia didn't look menacing in strategic priorities of the Soviet Union, are still divided by many experts in foreign policy in Russia told that the Russian Federation has more attractive partners in Asia-Pacific the region, than those which create Association of the Southeast Asian Countries (ASEAN) for example, Firstly, the Foreign policy of the Soviet Union created completely anti-Chinese line, but not the steady and conscious decision to affirm as the influential regional actor. It can brightly be illustrated by unwillingness of the Soviet Union - based generally on limited resources to expand its military presence out of the bases at Vietnam [26]. The main tendencies in the relations between Moscow and Hanoi, depth and which scale directly reflected dynamic of the Soviet-Chinese dialogue are 
other case in point. Secondly, the Soviet policy was ideologically oriented and therefore lacked flexibility for example, the downward tendencies prevailing in the relations between the Soviet Union and Indonesia from the 1960th to the 1980th years despite fundamental strategic need to strengthen communications with the most influential Southeast Asian country and ASEAN in 1967 which was noticed as "The Mini-organization of the southeast Asian agreement (CEATO)" and creation of a zone, free from nuclear weapon, in Southeast Asia as significantly important component of the Declaration on a zone of the world, freedom and a neutrality (ZOPFAN) which almost immediately became a cornerstone of the relations of an ASEAN with the main countries of the world [27]. Thirdly, the Soviet Union seriously underestimated increase in nationalism in both certain countries and Southeast Asia as all regions.

Therefore, very few numbers in the main Soviet management and experienced community had a proper understanding of amount and the nature of political and economic upgrade in the non-communistic states, and also their real motives to accelerate processes of regional integration [28].

The interests of an ASEAN in cooperation with the Soviet Union in the problem resolution of Cambodia. From the point of view of an ASEAN the Soviet Union could promote peace process, convincing Vietnam to take more constructive, conciliatory position and, eventually, to recall its troops from Cambodia. Besides, the ASEAN was concerned about the geopolitical problems facing it at the end of a Cold War [29]. Among potentially unstable areas there was the South China Sea where at least than 6 participants were locked in a long dispute on ownership of the Islands Spratli and Paracel Islands [30]. Now there was a good chance that these disputes will become more intensive. The help from the Soviet Union, an ASEAN shall be a role in balancing of the power and influence of the USA, the People's Republic of China and Japan in Southeast Asia.

Thus, Southeast Asia began to conduct good relations with the Soviet Union through the ASEAN organizations. The ASEAN was almost encouraging to comprehend its own regional interests more deeply, it could become a large number of a counterbalance to other three Asia-Pacific giants as People's Republic of China, Japan and the USA.

The Russian diplomacy began to turn more to Asia beginning approximately in the 19th. It noted the important Southeast Asian point. Energy export were the main initial incentive to the renewed Russian interest in Asia after the economic crisis in 1997-1998, but broader and more joint approach became obvious after Vladimir Putin became a president. In case of Putin, the Russian leaders were concentrated by methods to correct protection of the central power, an economic crisis and political problems. The foreign policy of Russia aimed to recover the friendly relations with the countries neighbors and to recover the Russian confidence and feeling of the purpose, finding new partners, especially in Asia. In foreign policy as Russia V. Putin aimed to understand, who were friends and opponents of Russia, Southeast Asia which as begin, received a new outstanding provision as the partner in policy and other frameworks.
In the 21st century, Russia considered important to emphasize that the Russian national interests in Southeast Asia within safety and the new military structure in this region will be created. Russia declared that multi-polarity was one of the basic principles of its foreign policy. Carrying out his politicians by the principles of multi-polarity helped Russia not only to advance the former friends in Southeast Asia but also and to modernize the relations with such important regional actors as the People's Republic of China and Japan.

Promotion of the relations with an ASEAN as one of the most important organizations in Southeast Asia plays the known role in the Russian foreign policy of multi-polarity. The relations between Russia and Southeast Asia were concentrated on a cooperation political both safety and presently the political role of Russia in the region became almost directly pro rata within trade and the economic relations with Southeast Asia [31]. It is possible to tell that, Political stability and economic dynamism in Southeast Asia are in national interest of Russia. The overview of national interests of Russia in Southeast Asia including, Russia plays roles to Southeast Asia through an ASEAN that contains important guarantees of stability and the world in the region; Russia will continue to be an important part of the liability of an ASEAN with main the countries in the world to become a part of a world political and economic system in the Pacific Rim; Influence of the People's Republic of China and the USA in the Pacific Rim paid their attention to the Russian foreign policy to protect national interests of Russia within the geopolitical competition of superpowers; Intervention disputes of the South China Sea because effective policy in East Asia of Russia both to help to increase export and to expand weapon of Russia and Southeast Asia also. All politicians of Russia in Southeast Asia, as cooperation with the states of Southeast Asia and an ASEAN to protect national interests of Russia as in the concept of foreign policy in system of the international relations in modern time.

\section{Specifics of national interests of Russia in Southeast Asia}

1.Political balance between the People's Republic of China and the USA which play roles in Southeast Asia.

Usually the policy of Russia in Southeast Asia doesn't draw a lot of attention. But they show important motives and subjects in full foreign policy of Russia and its answer to the increasing power of China and to tendencies in Asian safety. the Russian policy in Asia and in general. In particular they show searches of Russia of full independence and tactical flexibility, and also her usual confidence in energy and sales of weapon in the areas torn through fight as tools which it seeks to receive levers on regional agendas of safety [32]. Besides, they also show that as other powers, Russia pursues what it is possible to call the strategy of hedging against China in Asia. On the other hand, it supports China against the USA also to limit the Chinese power in Asia. Importance of Southeast Asia for Russia has constantly increased because of own center of Russia to Asia, for example, Russia has reached basing in Cam Ranh the gulf in Vietnam and recently announced the intention to pursue negotiations of rather sea bases in Singapore [33].Thus, Russia 
create new strategic foreign policy to protect national interests in Asia and Southeast Asia. Russia and China signed the agreement within a security guarantee and stability in the Pacific Rim as the Russian-Chinese cooperation against USA authorities because Russia tries for geopolitical independence in Asia and Southeast Asia.

2. Attention to military-political aspects of safety in Southeast Asia: on strengthening of military-political aspects of safety, expansion of weapon and nuclear weapon.

Political stability and economic dynamism in Southeast Asia are in national interest of Russia, Thus, Russia is important to have policy in support of military safety in Southeast Asia. In the same time, as a result Russia can expand arms supplies in this region which is compatible to the subsequent strengthening of economic dynamism of Russia [34]. Russia trains foreign armed forces to protect the national interests which were the countries in Southeast Asia. The role of foreign armed forces in Southeast Asia is considered as national interests of Russia because hardware of the Russian military which are an additional factor for bigger weapon deliver to other countries to benefit of the Russian manufacturers and the government budget and military bases and the Russian language schools in Laos, Vietnam and Cambodia create friendly military and political policy in many countries of the world.

Besides, Russia more and more becomes the interested safety and stability of vital water in the South China Sea and interest military-industrial and the energy companies in Southeast Asia to increase sales of weapon and military equipment in Southeast Asia. Thailand, Indonesia, Laos and Malaysia among other potential purposes of agreements on arms of Russia in the same time, Russian and the USA the relations in a cooperation in the sphere of safety in Southeast Asia to balance influence of the People's Republic of China.

The cooperation of the equipment of the Russian military to many Southeast Asian countries - first of all to Vietnam and Indonesia, to a lesser extent to Myanmar, Thailand and Malaysia [35]. The majority of these sales is based on typical defense contracts and, apparently, mainly, quite accidental, opportunistic nature. Russia would use the extensive inventories of military equipment as the tool to support presence in the region and to be related with the Southeast Asian countries for future economic cooperation, for example, Vietnam which became the largest buyer of the Russian defensive equipment as its purchase of opportunities like coastal protection clearly offers its strategic use as control to China in the South China Sea territorial disputes. Indonesia predominantly purchased military planes, despite his regular confidence in suppliers of the states of the North Atlantic Treaty Organization as has Myanmar though in much smaller scale and in others of the countries in Southeast Asia.

Now the Southeast Asian countries which achieved notable success in development of nuclear energy Vietnam,
Indonesia, Malaysia, Myanmar, Thailand and Philippines is. As any other regional market, the market of nuclear energy in Southeast Asia has own distinctive features which shall make mainly with geography and geology of area, thus, interest of Russia was expressed in programs of nuclear energy of area by other players of large-scale industry.

Russia increased the relations in this region. Russia gains a bigger impression on Southeast Asian affairs. Russia creates responsible for safety and stability in Southeast Asia to a form as military of reorganization, expanding investments into military weapons and building-up of military power as the budget of Russia in this region [36].The relations with Vietnam quickly develop also in other important spheres - in nuclear power, in joint oil production, and not only on the shelf of the South China Sea, but also in Western Siberia, in tourism. Return of the Russian fleet to Cam Ranh where it is planned to create logistics point is supposed. The construction plans of the free trade area expected prospect between two countries, and even accession of Vietnam to the Customs union of Russia, Belarus and Kazakhstan are developed. Thus, the policy of the Russian military and a cooperation of safety as weapon also extends, the power of Russia in Asia-Pacific countries shall pay attention to influence and arrived to dominate over a competition of China and the USA in Southeast Asia.

3. Problems of the South China Sea and national interests of Russia; A new role of Russia in the South China Sea.

Russia participates in this problem to protect national interests and foreign policy in the Pacific Rim and Southeast Asia. The need to solve the conflict around the South China Sea was one of factors, pushing Southeast Asia to forming of a military cooperation of Russia in this region. The islands Spratli are the reason of the conflicts in the South China Sea or certain parts them are required Brunei, China, Malaysia, Philippines, Taiwan and Vietnam and the Paracel Islands- an a matter in issue between China and Vietnam [37]. Since 1995 when Vietnam joined an ASEAN, there was a growing feeling that confrontation in the South China Sea any more not between six various parties, but generally between China and an ASEAN. All these territorial requirements and demands in reconvention - generally result of belief that this area is rich with oil and gas therefore many countries want to interfere in a problem, especially China, the USA and Russia. Why Russia shall interfere with this conflict.

Firstly, Russia wants to reduce influence of the People's Republic of China in the South China Sea. Russia aims to counterbalance the Chinese power not to influence Southeast Asia and the Pacific Rim. So, The Russian relations with the People's Republic of China and Southeast Asia in the context of the South China Sea - the good example of where Russia balances, to its regional interests is pleasant to play a role in Asia-Pacific the region.

Secondly, support of the Russian military to Vietnam is very profitable because the Russian trade in arms and energies and balance of forces China and the USA on safety which influence in the world. Al Lebite, the journalist in Manila told that, Russia aimed to contrast the reserved role in 
the region with those from the USA. Despite efforts of the Russian experts as Dmitry Trenin to represent the Russian sales of weapon to Vietnam and other Asian states as business decisions, some Chinese observers remain to be afraid of political consequences of these agreements. Li Jian, the researcher in the Chinese Naval Research institution, claimed in article on November 29, 2012 that the protection communications developing between Russia and Vietnam will probably complicate a problem of the South China Sea, especially for China. It is possible to tell that the Chinese and Russian competition through Southeast Asia within stability and safety in the region [38].

Thirdly, in the South China Sea, intervention of Russia because of benefit of a transfer of energy, sales of weapon and creation nuclear power plant in Southeast Asia.

4. The cooperation between Russia and ASEAN for developing of a role of superpowers in Eurasia.

Southeast Asia is important for Russia because, the region represents opportunities for Russia to play more influential role there and in East Asia [39]. Firstly, the ASEAN also plays an important role in East Asia. Therefore, ensuring its acceptance of the Russian participation in regional institutions is important for national interests of Russia. Secondly, the ASEAN is noticed as the increasing center of the power in Asia. The thorough relations could provide bigger balance in Asian policy of Russia, maintaining multipolar which guarantees the continuing Russian influence in international to the arena.Thirdly, an ASEAN - various participation which Russia appoints various a priority. Each country bears own value in search of Russia of regional influence. Therefore Russia tries to expand cooperation with an ASEAN.

Foreign policy Russia at the present stage recognized an important role of group in forming of regional institutions, such as within the Regional forum of ASEAN (HARPS), the East Asian Summit (EAS) and Conferences of Foreign Ministers of the countries of an ASEAN and the partner countries, Plans of Russia limited support of nuclear weapon of Southeast Asia - the Agreement on the Free zone and Russia supports communities ASEAN to 2015 also.

The Russian prospect on expansion of the relations with an ASEAN, that balance of forces of the People's Republic of China and the USA in the Pacific Rim and Southeast Asia; Secondly, ASEAN, one of the most important poles of the Russian "multi-polar world"; Thirdly, Russia succeeds in winning the place as "the great power in Southeast Asia”.

In other reasons for Russia to play a major role in Southeast Asia include: Russia wants to be a superpower in

Eurasia and East Asia, with a role through cooperation with China as strategic partnership with China. At the same time Russia develops the Far East of Russia and Siberia also.

Besides, Russia in Southeast Asia as pleasure, also continued to be considered as the European power, and not as an integral part Asia-Pacific the region. In this respect recently the head of Russia told that "Russia will shall improve the image which often doesn't correspond to real situation" [40]. It is possible to tell that, interest of Russia in redistribution of the power in the Pacific Rim resounds with other regional powers, such as the People's Republic of China, Australia and Japan. Respectively, Russia will have a potential to create new collars between Eurasia and the Pacific Rim.

From a point sight of prospect of the countries in Southeast Asia and the states of an ASEAN to reach Russia to play a role and participation in Southeast Asia because Russia - the strong country and is a role in East Asia and it as the key international actor. Thus, Russia will be able to give the country in Southeast Asia to the world scene in development of political and economic cooperation with the countries in the region and Southeast Asia can protect and recognize national interests from a role of Russia which it plays a role in this region.

\section{PERSPECTIVE AND INTERESTS OF THE RUSSIAN FEDERATION IN SOUTHEAST ASIA.}

The prospect of Russia in Southeast Asia will develop in the 21 st century. The key factors determining harmony of these relations is national interest from Russia and national interest of each of members of ASEAN, perception that each party has other and mutual trust constructed by means of collateral actions in various areas.

Russia developed cooperation in technology, both creation of a capability of society and Russia also offers the additional help to Cambodia, Laos, Myanmar and Vietnam. Russia will continue by an important part of the liability of an ASEAN with the leading powers, including the USA and the People's Republic of China. The cooperation of ASEAN Russia shall be structured, thus, readiness of Russia for closer dialogue and development of joint approaches to cross-border problems and the regional priority stand in its advantage. It will also make for more structured partnership in agreement performance about a cooperation of ASEAN Russia.

Besides, the Countries of Southeast Asia play the leading role in the new alignment of forces developing there. Therefore the shift of focus of the Russian foreign policy in partnerships in the region - at least, in that part which assumes development of such strategic areas as a military and technical cooperation, nuclear power, space and nanotechnologies - a tendency quite natural. It is necessary to carry to number of such countries: Indonesia, Malaysia and, to a lesser extent, Thailand, especially Vietnam, it was over the past few years beaten out in number of key partners of Russia in the region of Southeast Asia. It became possible thanks to a dense cooperation of two countries in such major areas as a military and technical cooperation and nuclear power. At the same time there are also prospects for further development; in a case with SEA is a further development of naval infrastructure, acquisition of anti-aircraft weapons by the Vietnamese side. So, the military and technical cooperation traditionally is strength of the Russian foreign policy. Russia continues to hold a position of the second country in the world on amounts of military export and within VTS with the countries of the region of Southeast Asia tries to make use of the accumulated experience, communications and reputation, including for 
deduction of former amounts of military export which, in turn, is the important budget item of Russia. Thus, Russia will protect the national interests in Southeast Asia as "a window of opportunities" to unite with the Pacific Rim on the global arena in the future.

\section{CONCLUSION}

The concept of foreign policy of the Russian Federation it was concentrated on a construction in the whole development of the country to stability and globalization in the political and economic sphere. In case of the president Vladimir Putin considers that, foreign policy - one of the most important tools to guarantee sustainable development of the country and to guarantee its competitiveness in the modern world. Foreign policy priorities of Russia it is concentrated on everyone the region in the world. As the foreign policy in case of the government of the president Vladimir Putin plans to develop Siberia and the Far East of Russia which have rich natural resources and importance for Russia. Russia aims to economic development in the region of Siberia. Moreover, Russia considers the mechanism the Summit of the countries of East Asia as the main platform for strategic dialogue between leaders in key problems of stability and safety. Thus, the new priorities of the Russian foreign policy in the region as the Pacific Rim and the Southeast Asia (SA) which represent the greatest interests and are considered the most dynamically developing geopolitical space and is considered as future center of worldwide policy and economy.

Southeast Asia is an important part in geopolitics of the Pacific Rim which becomes the significant center regional and international the relation. Now Southeast Asia represents the interests on the international scene. Russia was also concentrated on big threat and national interests in SEA in a political cooperation in the form of stability and safety and economic development through main the ASEAN organizations.

When Russia considers the place and a role of SEA which are important on the world scene therefore Russia wants to develop the relation with SEA to have influence in political the framework to stability and security, development of armed forces, trade in arms and energy and also development of society and culture. Russia considers that SEA- "window of opportunities", leads to presence in the Pacific Rim and and the world scene through main the ASEAN organizations.

Therefore in the 21 st century, Russia considered important to emphasize that the Russian national interests in SEA within safety and the new military structure in this region will be created. Russia declared that multi-polarity was one of the basic principles of its foreign policy, to protect national interests of Russia. Carrying out his politicians by the principles of multi-polarity helped Russia not only to advance the former friends in SEA but also and to modernize the relations with such important regional actors as the People's Republic of China and Japan.

The policy of Russia in Southeast Asia actively of a cooperation with the states of Southeast Asia and the Association of Southeast Asian Nations (ASEAN) takes now the important place in priorities of the Russian foreign policy on the Far East direction. Russia creates strengthening and diversification as a bilateral cooperation between Russia and the Southeast Asian countries. Moreover, the expansion of institutional base of a partnership between Russia and ASEAN in the form of the summits with participation of Heads of States and Governments.

Expansion of a role of Russia in SEA to make Russia more considerable partner for the states of an ASEAN, especially interaction of Russia and the states of Southeast Asia concerning stability and safety such as participation of Russia in activities of the Regional forum of ASEAN (HARPS), the Meeting of Ministers of Defense (MMD) of ACEAH+8, the Mutual declaration about partnership in a cause of peace and safety and the mutual declaration Russian Federation and ASEAN about a cooperation in fight against the international terrorism.

At the present time, the development of a cooperation of Russia in Southeast Asia infringes on interests of the world in wider structure for the cooperation in political and economic to the sphere. Southeast Asia became the largest center of foreign powers such as the USA, the People's Republic of China, Japan, etc. They are interested in creation of a stable and the flared markets and energy weapon. Therefore, Russia will try to have influence in this region and will protect national interests of Russia and including implementation of the Russian foreign policy in relation to Asia to play a major role in Asia-Pacific the region and Southeast Asia in the future.

\section{REFERENCES}

[1] Amador J, ASEAN in the Power. the diplomat, vol. 2, 2013, pp. 29-35.

[2] ASEAN Foundation. ASEAN Foundation Supports the Promotion of Role and Participation of Foreign Policy Study Groups in ASEAN Community Building, vol. 13, 2004, pp. 123-135.

[3] ASEAN Political - Security Community Blueprint, vol. A247, 2012, pp 25-35.

[4] Association of Southeast Asian Nations. ASEAN - Russia, vol.4, 2012, pp. 56-67.

[5] Aziz F. Forge ahead through ASEAN, vol. 12, 2014, pp. 78-82.

[6] Blank S. Russia's Growing Ties with Vietnam.The diplomat, vol. 13, 2014, pp. 23-35.

[7] Chang F.K. A salutation to Arms: Asia's Military Buildup, Its Reason, and ITs Implications; Foreign Policy Research Institute. - 2013. vol. A 24, 2012, pp.23-34

[8] Goltsblat A. Russia Goes Global - Southeast Asia; The Moscow Times, vol.15, 2013, pp. 24-36.

[9] Giusti S. Russia's Foreign Policy for the country's stability, vol. 12, 2013, pp. 45-57.

[10] Haji Z. The political Future of ASEAN after the Asian crisis, vol. 75, 2014, pp. 124-143.

[11] Kanaev E. Southeast Asia in Russia's Foreign Policy under D.Medvedev, vol. 3, 2010, pp. 4-8.

[12] Kharlamov I. Russia: Foreign policy priorities formulated, vol. 21, 2012, pp. 56-68.

[13] Kireeva A. Russia's East Asia Policy: New Opportunities and Challenges, vol. 12, 2012, pp. 87-98

[14] Klyuchanskaya S. Nuclear Energy in Southeast Asia and Russia's Interests; A Russian Journal on International Security, vol. 4, 2011, pp. 66-78.

[15] Kovtun A.G. Russia fosters strategic partnership with Vietnam: the voice of Vietnam, vol. 12, 2013, pp. 11-24. 
[16] Kozyrev V. Russia's New Asia Strategy: Assessing Russia's Eastward Pivot, vol. 13, 2013, pp. 51-67.

[17] Kucera W. Russia's Quiet Partnerships in Southeast Asia - Russia Malaysia Strategic Partnership through Sabah Case Study, vol. 3, 2015 pp. 234-246.

[18] Kyodo News International. ASEAN+8 security forum to push for stronger security cooperation, vol. 3, 2014, pp. 52-65.

[19] Lavrov S.V. Russia and ASEAN can Achieve a great deal together, vol. 5, 2015, pp. 46-58.

[20] Lina A.A. ASEAN Political - Security Community in 2015: Is it possible?, vol. 7, 2011, pp. 267-278.

[21] Lukyanov F. Uncertain World: Foreign Policy - Breaking Away From National Interests, vol. 4, 2013, pp. 14-28.

[22] Mohammed A. Asia-Pacific stability depends on success of ASEAN code of conduct-Kerry, vol. 5, 2014, pp. 156-168.

[23] Monaghan A. The New Russian Foreign policy Concept: Evolving Continuity, vol. 25, 2013, pp. 34-45.

[24] New times Analytical Information. Russia's new foreign policy concept: key aspects, vol. 17, 2013, pp. 78-89.

[25] Permanent Mission of the Russian Federation to the European Union. Russian Foreign Policy, vol. 21, 2013, pp. 136-145.

[26] Prospects for Nuclear Security Partnership in Southeast Asia, vol. 23 , 2014, pp. 52-55.

[27] Rangimaporn P. Russia's Search for Influence in Southeast Asia, vol. 5 , 2015, pp. 120-134.
[28] Russia Beyond the headlines. Russia names its top foreign policy priorities, vol. 4, 2012, pp.34-46.

[29] Sam C.Y. A Study of Russian-Southeast Asian Relations in the Putin Era, vol.4, 2013, pp. 87-99.

[30] Saravanamuttu J. Malaysia in the New Geopolitics of Southeast Asia :The New Geopolitics of Southeast Asia, vol. 5, 2012, pp.256-268.

[31] Shekhar V. ASEAN in 2013: Coming out of the Clouds,. - vol. 5, 2013, pp. 34-46.

[32] Snitwongse K. Thirty years of ASEAN Achievements through political cooperation, vol. 14, 2011, pp. 22-34.

[33] Son N.H. The ASEAN Political Security Community: Challenges and Prospect, Institute for Foreign policy and Strategic Studies, vol. 12, 2013, pp.44-56.

[34] Sumsky V. Russia and ASEAN: emerging partnership in the 1990s and the security of South-East Asia, vol. 187, 2013, pp. 45-67.

[35] Taylor C. Military Balance in Southeast Asia, vol. 3, 2011, pp. 56-67.

[36] Thayer C. South China Sea: Regional States Push Back Against China ,vol. 5, 2014, pp. 12-25.

[37] Thayer C. The Bear is Back: Russia Returns to Vietnam, vol. 14, 2011, pp.34-46.

[38] The Minister of foreign Affairs of the Russian Federation. Concept of the Foreign Policy of the Russian Federation, 2013, pp. 13-25.

[39] Tofani R. Russia rebuilds ties with Vietnam, vol. 5, 2014, pp. 45-57. 